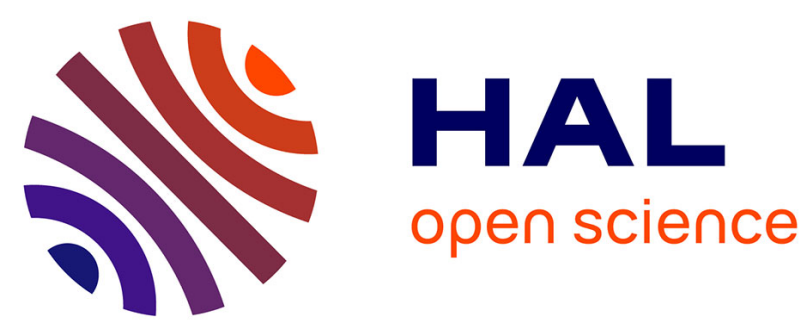

\title{
Mini-broncho-alveolar lavage: a simple and promising method for assessment of antibiotic concentration in epithelial lining fluid.
}

\author{
Olivier Mimoz, Claire Dahyot-Fizelier
}

\section{To cite this version:}

Olivier Mimoz, Claire Dahyot-Fizelier. Mini-broncho-alveolar lavage: a simple and promising method for assessment of antibiotic concentration in epithelial lining fluid.. Intensive Care Medicine, 2007, 10.1007/s00134-007-0689-9 . inserm-00164751

\section{HAL Id: inserm-00164751 https://www.hal.inserm.fr/inserm-00164751}

Submitted on 23 Jul 2007

HAL is a multi-disciplinary open access archive for the deposit and dissemination of scientific research documents, whether they are published or not. The documents may come from teaching and research institutions in France or abroad, or from public or private research centers.
L'archive ouverte pluridisciplinaire $\mathbf{H A L}$, est destinée au dépôt et à la diffusion de documents scientifiques de niveau recherche, publiés ou non, émanant des établissements d'enseignement et de recherche français ou étrangers, des laboratoires publics ou privés. 
The original publication is available at www.springerlink.com

Editorial for manuscript \#ICM-2006-00757.R1 "Reliability of mini-bronchoalveolar lavage for the measurement of epithelial lining fluid concentrations of tobramycin in critically ill patients" by Boselli and colleagues.

Mini broncho-alveolar lavage: a simple and promising method for antibiotics concentration assessment in epithelial lining fluid.

Olivier Mimoz*, MD, PhD \& Claire Dahyot-Fizelier, MD

Pharmacologie des Agents Anti-Infectieux, INSERM, ERI023, and University of Poitiers, Poitiers, France.

${ }^{*}$ Corresponding author

o.mimoz@chu-poitiers.fr

Tel: +33549444230

Fax: +33549444229

Key-words: critical care, nosocomial infection, ventilator-associated pneumonia, pharmacokinetics, epithelial lining fluid 
Nosocomial infections remain the most frequent complication associated with hospitalization, presenting a serious burden in terms of health care costs, morbidity and possibly mortality. Ventilator associated pneumonia (VAP) is the leading cause of nosocomial infection in critically ill patients requiring mechanical ventilation, with a risk ranging from $9 \%$ to $27 \%$ and an incidence rate of 5 to 10 cases per 1000 ventilator-days (1). The presence of VAP increases hospital stay by an average of 7 to 9 days per patient and has been reported to produce an excess cost of more than $€ 30,000$ per patient (2). The crude mortality rate for VAP may be as high as $30 \%$ to $70 \%$, but many of these critically ill patients with VAP die of their underlying disease rather than pneumonia (1).

Inadequate antibiotic therapy further increases morbidity, mortality and costs of VAP. Optimization of treatment is therefore crucial and depends on the choice of an effective antibiotic and an optimal dosing regimen using pharmacokinetics-pharmacodynamic approaches (2). These usually rely upon plasma concentrations although most infections develop in deep tissues. Complete and lasting equilibration between antibiotic plasma and biophase (i.e., tissue site where antibiotic and pathogens interacted) concentrations cannot be taken for granted (3). Sub-optimal antibiotic concentrations may lead to therapeutic failure especially for bacteria for which in vitro MICs are high and is a key issue for emergence of bacterial resistance (2). Consequently, direct target site concentration measurements might be more relevant in predicting clinical response than the estimation of tissue concentration from those in the plasma.

Several techniques have been employed to monitor antibiotic concentrations in lung tissue of critically ill patients. Traditional concentration measurements in lung biopsies present ethical limitations and are of limited values because of tissue heterogeneity. Total concentrations in homogenized tissue lead to over- or under-estimation of actual antibiotic concentrations in the extra-cellular fluid depending on the ability of the drug to concentrate into cells (3). Microdialysis as recently emerged and is probably the method of choice when the biophase is the interstitial fluid (4). This method is based on the use of 
probes with a semi-permeable membrane at the probe tip. Microdialysis probes are implanted into the tissue of interest and constantly perfused with a physiological solution. Substances in the interstitial fluid pass through the membrane by passive diffusion along their concentration gradient and dialysates are collected at time intervals. Equilibration of antibiotic concentrations between the interstitial fluid and the dialysates is rarely reached and microdialysis probes must be calibrated individually in vivo. This process is time consuming and limits the application of the method in patients during lung surgery (5-7). Epithelial ling fluid (ELF) is also thought to reflect the biophase for pulmonary infections induced by extra-cellular pathogens (8). ELF can be easily sampled by broncho-alveolar lavage (BAL) using typically a bronchoscope and three 50-ml syringes of saline. However interpretation of the results is hindered by many confounding factors. First the antibiotic concentration measured in BAL sample must be corrected for drug free saline added during the procedure to obtain actual concentration in ELF. This correction is usually performed by measuring urea content, an endogenous marker able to travel across membranes freely, in BAL and plasma samples. Dwelling time of fluid during BAL procedure can be a source of error with the urea method. In situations where the dwelling time is over 1 min, ELF volume is expected to be overestimated by $100-300 \%$ due to additional urea diffusion from the interstitium and other tissues (9). Furthermore the accuracy of urea assays in diluted ELF may also be questionable. Secondly cells, especially alveolar macrophages, are present in ELF. For antibiotics that accumulate into cells, such as macrolides or fluoroquinolones, lysis of some or all cells could artificially increase the measured ELF concentration of the antibiotic, the amount of error varying with the amount in the cells and the numbers of cells present (10). Thirdly in contrast to microdialysis which allows sequential sampling over time, concentration measurements in ELF samples only yield a limited number of time points, usually one. Lung to plasma antibiotic concentrations ratios should vary widely according to the time of sampling after antibiotic administration as illustrated in Figure 1, leading to misinterpretation of drug tissue distribution. All these confounding factors may contribute to the large inter studies variability. 
As an example ELF to plasma ratios of $100 \%$ (11), $300 \%$ (12) and $800 \%$ (13) were reported for linezolid. Recently Boselli et al. have used a small volume non-bronchoscopic BAL ("mini-BAL") (11, 14-18), however up to know comparisons between this new method and the conventional bronchoscopic BAL were lacking.

In this issue of the Journal, these authors have reported the results of the first study comparing mini-BAL and conventional BAL for the assessment of antibiotic concentration in ELF (19). For that purpose they studied 12 mechanically ventilated critically ill patients with suspected VAP. Subjects received 30-min intravenous infusions of tobramycin $7 \mathrm{mg} / \mathrm{kg}$ once daily. At day 2 each patient underwent standardized fibroscopic broncho-alveolar sampling by infusing three $50-\mathrm{mL}$ aliquots of sterile $0.9 \%$ saline solution 30 min after the end of tobramycin infusion. Immediately after, mini-BAL procedure was done with $40-\mathrm{mL}$ of sterile $0.9 \%$ saline solution. A good agreement was found between the two methods and the authors concluded that mini-BAL could be substituted to conventional BAL since it is simple, less invasive and easily repeatable. These results are interesting since mini-BAL do not require specific material or particular expertise and can be performed in virtually all intensive care units. Moreover since bronchoscopy is needless and volume administered low, respiratory tolerance might be improved compared to the reference method. ELF to plasma concentration of tobramycin was determined 30 min after the end of a 30 min infusion and found equal to only $12 \%$ on average. This may be due to a slow tissue distribution of this antibiotic since Carcas and colleagues, obtained a ratio of $30 \%$ at $30 \mathrm{~min}$ and $150 \%$ at $8 \mathrm{~h}(20)$.

The mini-BAL technique could possibly be repeated in a same patient offering therefore the possibility of collecting data at various times after antibiotic administration to describe the distribution process over time. As such the mini-BAL technique appears to be a very promising approach to characterize antibiotics lung distribution. 


\section{References}

1. American Thoracic Society \& Infectious Diseases Society of America (2005) Guidelines for the management of adults with hospital-acquired, ventilator-associated, and healthcare-associated pneumonia. Am J Respir Crit Care Med 171:388-416

2. Craig WA (1998) Pharmacokinetic/pharmacodynamic parameters: rationale for antibacterial dosing of mice and men. Clin Infect Dis 26:1-10

3. Joukhadar C, Frossard M, Mayer BX, Brunner M, Klein N, Siostrzonek P, Eichler HG, Müller M (2001) Impaired target site penetration of beta-lactams may account for therapeutic failure in patients with septic shock. Crit Care Med 29;385-391

4. Müller M, de la Pena A, Derendorf H (2004) Issues in pharmacokinetics and pharmacodynamics of anti-infective agents: distribution in tissue. Antimicrob Agents Chemother 48:1441-1453.

5. Tomaselli F, Maier A, Matzi V, Smolle-Juttner FM, Dittrich P (2004) Penetration of meropenem into pneumonic human lung tissue as measured by in vivo microdialysis. Antimicrob Agents Chemother 48:2228-2232.

6. Dahyot C, Marchand S, Pessini GL, Pariat C, Debaene B, Couet W, Mimoz O (2006) Microdialysis study of imipenem distribution in skeletal muscle and lung extracellular fluids of Acinetobacter baumannii-infected rats. Antimicrob Agents Chemother 50:2265-2267.

7. Marchand S, Dahyot C, Lamarche I, Mimoz O, Couet W (2005) Microdialysis study of imipenem distribution in skeletal muscle and lung extracellular fluids of noninfected rats. Antimicrob Agents Chemother 49:2356-2361.

8. Mimoz O, Rolland D, Adoun M, Marchand S, Breilh D, Brumpt I, Debaene B, Couet W (2006) Steadystate trough serum and epithelial lining fluid concentrations of teicoplanin $12 \mathrm{mg} / \mathrm{kg}$ per day in patients with ventilator-associated pneumonia. Intensive Care Med 32:775-779 
9. Baldwin DR, Honeybourne D, Wise R (1992) Pulmonary disposition of antimicrobial agents: methodological considerations. Antimicrob Agents Chemother 36:1171-1175.

10. Andrews JM, Honeybourne D, Jevons G, Brenwald NP, Cunningham D, Wise R (1997) Concentrations of levofloxacin (HR 355) in the respiratory tract following a single oral dose in patients undergoing fibre-optic bronchoscopy. J Antimicrob Chemother 40:573-577

11. Boselli E, Breilh D, Rimmele T, Djabarouti S, Toutain J, Chassard D, Saux MC, Allaouchiche B (2005) Pharmacokinetics and intrapulmonary concentrations of linezolid administered to critically ill patients with ventilator-associated pneumonia. Crit Care Med 33:1529-1533.

12. Honeybourne D, Tobin C, Jevons G, Andrews J, Wise R (2003) Intrapulmonary penetration of linezolid. J Antimicrob Chemother 51:1431-1434.

13. Conte JE Jr, Golden JA, Kipps J, Zurlinden E (2002) Intrapulmonary pharmacokinetics of linezolid. Antimicrob Agents Chemother 46:1475-1480

14. Boselli E, Breilh D, Rimmele T, Poupelin JC, Saux MC, Chassard D, Allaouchiche B (2004) Plasma and lung concentrations of ceftazidime administered in continuous infusion to critically ill patients with severe nosocomial pneumonia. Intensive Care Med 30:989-991

15. Boselli E, Breilh D, Cannesson M, Xuereb F, Rimmele T, Chassard D, Saux MC, Allaouchiche B (2004) Steady-state plasma and intrapulmonary concentrations of piperacillin/tazobactam $4 \mathrm{~g} / 0.5 \mathrm{~g}$ administered to critically ill patients with severe nosocomial pneumonia. Intensive Care Med 30:976-979. 16. Boselli E, Breilh D, Rimmele T, Djabarouti S, Saux MC, Chassard D, Allaouchiche B (2005) Pharmacokinetics and intrapulmonary diffusion of levofloxacin in critically ill patients with severe community-acquired pneumonia. Crit Care Med 33:104-109.

17. Boselli E, Breilh D, Saux MC, Gordien JB, Allaouchiche B (2006) Pharmacokinetics and lung concentrations of ertapenem in patients with ventilator-associated pneumonia. Intensive Care Med 32:2059-2062 
18. Boselli E, Breilh D, Duflo F, Saux MC, Debon R, Chassard D, Allaouchiche B (2003) Steady-state plasma and intrapulmonary concentrations of cefepime administered in continuous infusion in critically ill patients with severe nosocomial pneumonia. Crit Care Med 31:2102-2106.

19. Boselli E (2007) Intensive Care Med

20. Carcas AJ, Garcia-Satue JL, Zapater P, Frias-Iniesta J (1999) Tobramycin penetration into epithelial lining fluid of patients with pneumonia. Clin Pharmacol Ther 65:245-250.

21. Richer M, Allard S, Manseau L, Vallee F, Pak R, LeBel M (1995) Suction-induced blister fluid penetration of cefdinir in healthy volunteers following ascending oral doses. Antimicrob Agents Chemother 39:1082-1086. 
Figure. Concentration-time profile of cefdinir in plasma $(\bullet)$ and in blister fluid $(\circ)$ after an oral single 600 $\mathrm{mg}$ dose. The simultaneous blister fluid/plasma concentration ratios were $<1$ during the first $6 \mathrm{~h}$ and $>1$ thereafter. Interestingly, area under the curve in blister fluid to the area under the curve in plasma, a better parameter to represent tissue penetration of antibiotics, was near 1. Adapted from (21)

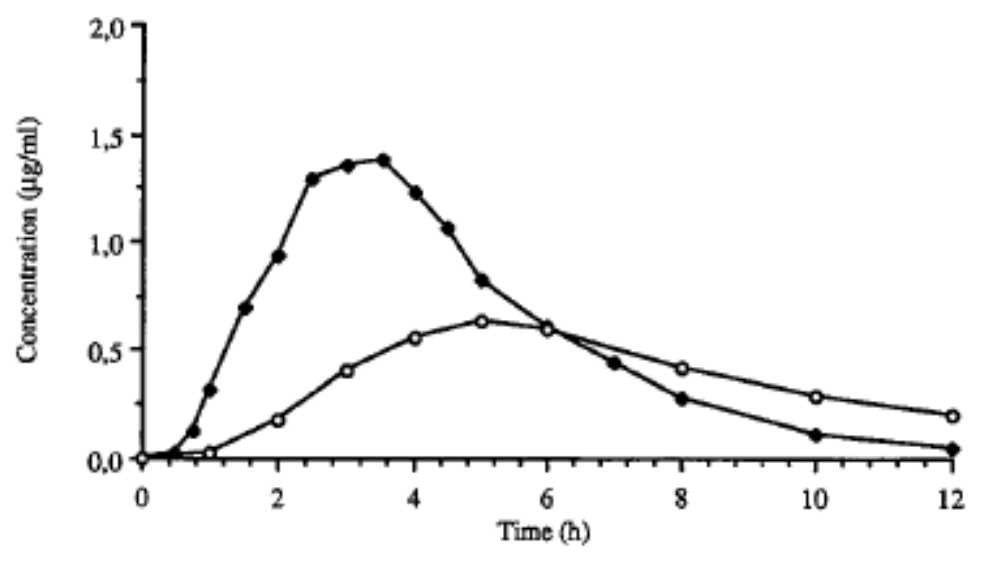

